\title{
Short interspersed CAN SINE elements as prognostic markers in canine mammary neoplasia
}

\author{
GABRIELA B. GELALETI ${ }^{1,2}$, ADRIANA GRANZOTTO ${ }^{3}$, CAMILA LEONEL $^{1,2}$, BRUNA V. JARDIM ${ }^{1,2}$, \\ MARINA G. MOSCHETTA ${ }^{2,4}$, CLAUDIA M.A. CARARETO ${ }^{3,5}$ and DEBORA AP.P.C. ZUCCARI ${ }^{2,6}$ \\ ${ }^{1}$ Program of Post-Graduate in Genetics, UNESP - São Paulo State University; ${ }^{2}$ Laboratório de Investigação \\ Molecular do Câncer, FAMERP - Faculty of Medicine of São José do Rio Preto; ${ }^{3}$ Laboratório de Evolução \\ Molecular de Insetos, UNESP - São Paulo State University; ${ }^{4}$ Program of Post-Graduate in Health Science, \\ FAMERP - Faculty of Medicine of São José do Rio Preto; ${ }^{5}$ Department of Biology, UNESP - São Paulo State \\ University; ${ }^{6}$ Department of Molecular Biology, FAMERP - Faculty of Medicine of São José do Rio Preto and \\ Program of Post-Graduate in Genetics, UNESP - São Paulo State University, São José do Rio Preto, São Paulo, Brazil
}

Received August 28, 2013; Accepted October 4, 2013

DOI: $10.3892 / o r .2013 .2827$

\begin{abstract}
The genome of mammals is characterized by a large number of non-LTR retrotransposons, and among them, the CAN SINEs are characteristics of the canine species. Small amounts of DNA freely circulate in normal blood serum and high amounts are found in human patients with cancer, characterizing it as a candidate tumor-biomarker. The aim of this study was to estimate, through its absolute expression, the number of copies of CAN SINE sequences present in free circulating DNA of female dogs with mammary cancer, in order to correlate with the clinical and pathological characteristics and the follow-up period. The copy number of CAN SINE sequences was estimated by qPCR in 28 female dogs with mammary neoplasia. The univariate analysis showed an increased number of copies in female dogs with mammary tumor in female $\operatorname{dogs}>10$ years old $(\mathrm{p}=0.02)$ and tumor time $>18$ months $(\mathrm{p}<0.05)$. The Kaplan-Meier test demonstrated a negative correlation between an increased number of copies and survival time $(\mathrm{p}=0.03)$. High amounts of CAN SINE fragments can be good markers for the detection of tumor DNA in blood and may characterize it as a marker of poor prognosis, being related to female dogs with shorter survival times. This estimate can be used as a prognostic marker in non-invasive breast cancer research and is useful in predicting tumor progression and patient monitoring.
\end{abstract}

Correspondence to: Dr Debora Ap. Pires de Campos Zuccari, Laboratório de Investigação Molecular do Câncer, FAMERP - Faculty of Medicine of São José do Rio Preto, Brigadeiro Faria Lima 5416, 15090.000 São José do Rio Preto, São Paulo, Brazil

E-mail: debora.zuccari@famerp.br

Key words: mammary cancer, circulating DNA, CAN SINE, prognostic

\section{Introduction}

The canine mammary gland tumor is considered as an appropriate model for the study of human mammary cancer $(1,2)$, since these tumors share histopathological and biological characteristics and it is also useful for testing therapeutic agents $(3,4)$. The current growing interest of cancer researchers in these models and the increasing number of publications in veterinary oncology make this comparison of great importance, allowing the rapid and valid transfer of data for clinical application in human (5).

The genetic analysis of the dog (Canis familiaris) is easier nowadays due to a variety of resources which were pointed out by Bentolila et al (6), that include a standard canine karyotype (7), physical mapping tools (8-11), highly polymorphic genetic markers $(12,13)$, canine-rodent hybrid cell lines (11), linkage groups (14) and a linkage map (13). Since the domestic dog is a good alternative as a mammalian model for a number of diseases and phenotypes, Bentolila et al (6) reinforce that it is important to have further studies once the canine genome is more clearly understood.

The mammalian genomes are characterized by a large number of repetitive DNA sequences, many of which are remnants of transposable elements (TEs) $(6,15-17)$. These repetitive sequences can be classified, according to their transposition mechanism, into two classes: i) Class I or retrotransposons, which are sequences that move via an RNA intermediate. They can be divided into five orders, the LTR retrotransposons, DIRS-like elements, Penelope-like elements (PLEs), LINEs (long interspersed nuclear elements) and SINEs (short interspersed nuclear elements); and ii) Class II elements, which replicate without an RNA intermediate by a mechanism called 'cut-and-paste' and can be classified as Subclass 1 and 2 (18).

The SINEs, especially CAN SINEs, the focus of this study, are repetitions with genomic DNA 80-500 bp in length, often enriched in $\mathrm{CpG}$, apparently arising from accidental retrotransposition of multiple transcripts from polymerase III 
(Pol III) (tRNA, 7SL RNA and 5S RNA). SINE sequences were found first in primates and rodents, but now it is generally accepted that several SINE families are present in higher eukaryotes (6). In carnivores, CAN short retroposons are typical tRNA related highly repeated SINEs [ 400.000 bp in the haploid genome of the dog $(6,19)]$.

The best known SINE is Alu, that began to amplify early in primate evolution and is one of the most successful mobile elements. The human genome $(>10 \%)$ is represented by these elements, which comprise approximately one million copies. This high copy number creates a large number of insertion mutations resulting in human disease or genome evolution and the high level of genetic instability contributes to a significant number of germ-line mutations and is an important factor in cancer and/or aging (20).

Present understanding of the molecular mechanisms involved in cancer means that there is an increasing use of diagnostic strategies. Many of the genetic changes involved in tumorigenesis are now time-sequenced, as also occurs with tumors which liberate nucleic acids into various biological fluids, including blood. Thus, the detection of such genetic alterations (those associated with tumor development) in circulating DNA (ctDNA) is a logical new approach as a noninvasive, diagnostic or theranostic test for cancer (21). ctDNA has been observed and described in the plasma, serum and body fluids of pregnant patients, those patients with severe trauma and other patients with different diseases, such as autoimmune disease and cancer (22). It was first observed in plasma samples in 1948 by Mandel and Metais (23) and, only later, Stroun et al (24) determined that ctDNA in the plasma of cancer patients originated from tumor cells.

It is accepted that solid malignant tumors release a significant amount of genomic DNA into the systemic circulation (25). The source of ctDNA is still not fully understood, but it has been suggested that necrosis, apoptosis, phagocytosis, direct release and release from macrophages/scavengers following absorption of necrotic cells may play a role (26-31).

The general diagnostic value of simple quantitative measures of circulating DNA is controversial. Further work on the use of ctDNA as a diagnostic marker for neoplasia included the detection of qualitative rather than quantitative differences, such as specific oncogene mutations, loss of heterozygosity, specific Alu amplicons, and methylation patterns found in plasma or serum, and matching them with DNA characteristics in primary tumors (32).

Studies involving dogs with this approach are not found in the literature therefore the aim of this study was to estimate, through its absolute expression, the number of copies of CAN SINE sequences present in free circulating DNA of female dogs with mammary cancer in order to correlate this with the clinical and pathological characteristics and the follow-up period.

\section{Materials and methods}

Sample characterization. Peripheral blood samples and tumor fragments from 28 female dogs were collected. The control group consisted of 50 non-affected female dogs. After tumor excision and blood collection, the animals were examined at intervals of one, six and 12 months, by new blood sampling. The age of the animals varied from 6 to 16 years (mean, 10 years). Most of the tumors were classified as malignant (89\%) and consisted mostly of the mixed carcinoma form. The local recurrence rate was $28 \%$, metastasis $18 \%$ and death $32 \%$ (Table I). The exclusion criteria for the control group were rigorously followed and included females outside the estrus period, with no history of tumors and no detectable disease inflammation/infections in the period before the sampling. We included animals with variable age and breed, besides that, it was verified that the animals were not subjected to surgery in the previous period.

Tumor fragments were fixed in buffered $10 \%$ formaldehyde for $24 \mathrm{~h}$ and paraffin-embedded. Histological sections $(5 \mu \mathrm{m})$ were obtained and stained with hematoxylin and eosin (H\&E) for histopathology. Tumor grading was done according to Misdorp et al (33) by the AFIP (Armed Forces Institute of Pathology). This study was approved by the Comite de Ética no Uso de Animal (CEUA) - Animal Ethics Committee/ FAMERP (protocol no. 3945/2009).

Female dogs from the test group were evaluated with respect to physical (breed and age), pathological (time course - interval between tumor diagnosis and surgical removal, tumor nodules location, lymph node involvement, tumor size, clinical staging, ulceration and vascularization) and clinical (metastasis, tumor recurrence and death) characteristics. The parameters employed for the classification of clinical tumor grading were in accordance with the TNM system (size, lymph node involvement and metastasis) established by the World Health Organization (WHO) for canine mammary gland tumors [modified from Cassali et al (34)]. Clinical grading was assigned as I, II, III or IV according to the tumor size and established prognosis.

Plasma sample collection. Blood ( $3 \mathrm{ml})$ was collected in a CORVAC serum separator tube (Labor Import Co., Sao Paulo, Brazil) containing clot activation additive and barrier gel, stored at $4^{\circ} \mathrm{C}$ and processed within $6 \mathrm{~h}$ : the tubes remained in a water bath for $15 \mathrm{~min}$ at $37^{\circ} \mathrm{C}$ and the blood was separated by centrifugation $(1000 \mathrm{x} \mathrm{g}, 25 \mathrm{~min})$. The serum was immediately cryopreserved at $-80^{\circ} \mathrm{C}$.

Cloning and estimation of CAN SINE copy number. Serum samples selected for cloning were submitted to a pre-treatment to deactivate or eliminate proteins binding to template DNA. For this, $10 \mu \mathrm{l}$ of serum sample was mixed with $0.1 \mathrm{ml}$ of DNAzol ${ }^{\circledR}$ Direct (Molecular Research Center Inc., Cincinnati, $\mathrm{OH}, \mathrm{USA}$ ) according to manufacturer's conditions. CAN SINE sequences were amplified by PCR reaction using specific primers CAN SINE: 5'-CTGGGTGGCTCAGTCRGT-3' and 5'-AGCACAGAGCCYGAYGYG-3' (19) that amplify $174 \mathrm{bp}$. The sequences amplified were purified with the GFX kitIllustra GFX PCR DNA and Gel Band Purification kit (GE Healthcare), measured through a $1 \%$ agarose gel stained with ethidium bromide and subsequently used for cloning.

The CAN SINE sequence was cloned into the Topo TA vector $^{\circledR}$ plasmid, using the $\mathrm{TOPO}^{\circledR} \mathrm{TA}^{\mathrm{T}}$ Cloning kit (Invitrogen) according to manufacturer's conditions in competent cells (One Shot ${ }^{\circledR}$ TOP10 Chemically Competent E. coli). The presence of insert using primers M13F and M13R was investigated in colonies. Subsequently extraction was performed using the plasmid phenol-chloroform. The presence of the CAN SINE sequence in the plasmid was confirmed by restriction profile 
(restriction enzymes in different combinations were used with enzyme cuts at different positions of the plasmid with the enzymes HindIII, EcoR1, XmaI +EcoR1 and XmaI +KpnI) (Invitrogen) and sequencing.

The linearized plasmid was obtained by digestion by the enzyme HindIII (Invitrogen) according to manufacturer conditions. After digestion, the material was purified using the GFX PCR DNA and Gel Band Purification kit (GE Healthcare) and quantified by NanoDrop 1000 Spectrophotometer (Thermo Scientific). A final concentration of $83.6 \mathrm{ng} / \mu \mathrm{l}$ for the linearized plasmid with the CAN SINE sequence was established. The estimated number of copies of the sequence of interest was calculated using the formula, according to Zhang and Fang (35) and Liang et al (36):

$$
\frac{X \text { g/ } \mu \text { l DNA }}{\text { size of the oligo bp } \times 649} \times 6.022 \times 10^{23}
$$

Absolute quantification by real-time ( $q R T-P C R)$. The number of copies of the CAN SINE sequence for each sample was calculated using the absolute quantification by real-time PCR. To deactivate or eliminate proteins binding to template DNA that might invalidate qRT-PCR results, a pre-treatment of samples was necessary following the protocol of Umetani et al (37) modified, $20 \mu \mathrm{l}$ of each serum sample was mixed with $20 \mu \mathrm{l}$ of a preparation buffer that contained $2.5 \%$ of Tween-20, $50 \mathrm{mmol} / \mathrm{l}$ Tris and $1 \mathrm{mmol} / \mathrm{l}$ EDTA. This was digested with $16 \mu \mathrm{g}$ of proteinase $\mathrm{K}$ solution (Qiagen, Valencia, CA, USA) at $37^{\circ} \mathrm{C}$ overnight, followed by $5 \mathrm{~min}$ of heat deactivation and insolubilization at $95^{\circ} \mathrm{C}$. After subsequent centrifugation (10000 x g, $5 \mathrm{~min}$ ), the supernatant was stored at $-20^{\circ} \mathrm{C}$ for later quantification in NanoDrop 1000 Spectrophotometer (Thermo Scientific).

The reaction mixture for each qRT-PCR consisted of a template sequence $10 \mathrm{pmol} / \mu \mathrm{l}$ of the forward and reverse CAN SINE primers, the same used for cloning, $100 \mathrm{ng} / \mu 1$ of sample and system detection Master Mix SYBR ${ }^{\mathrm{TM}}$ Green (Applied Biosystems). The absolute equivalent amount of DNA in each sample and the initial concentration of genomic DNA from the constructed plasmid were determined by a standard curve with serial dilutions. In each reaction, a standard curve was included corresponding to a baseline distinguishing the number of copies and five serial dilutions and analyses where performed to estimate the number of copies of the target sequence in each sample.

The amplification was performed with pre-cycling heat activation of DNA polymerase at $95^{\circ} \mathrm{C}$ for $10 \mathrm{~min}$, followed for initial denaturation at $95^{\circ} \mathrm{C}$ for $15 \mathrm{~min}$ and $60^{\circ} \mathrm{C}$ for $1 \mathrm{~min}$. For the melt-stage curve, the program continued with 40 cycles of $15 \mathrm{sec}$ at $95^{\circ} \mathrm{C}, 1 \mathrm{~min}$ at $60^{\circ} \mathrm{C}$ for annealing of primers and extension of the chains, followed by $15 \mathrm{sec}$ at $95^{\circ} \mathrm{C}$ to collect the signal using Real-Time PCR System Step One Plus (Applied Biosystems). A negative control (without template) was performed for each plate. All qRT-PCR assays were performed in a blinded fashion without knowledge of specimen identity. Mean values were calculated from triplicate reactions.

Statistical analysis. The results were first submitted to descriptive analyses for the determination of normality and were considered to have a normal distribution. The different clinicopathological characteristics and quantifications were
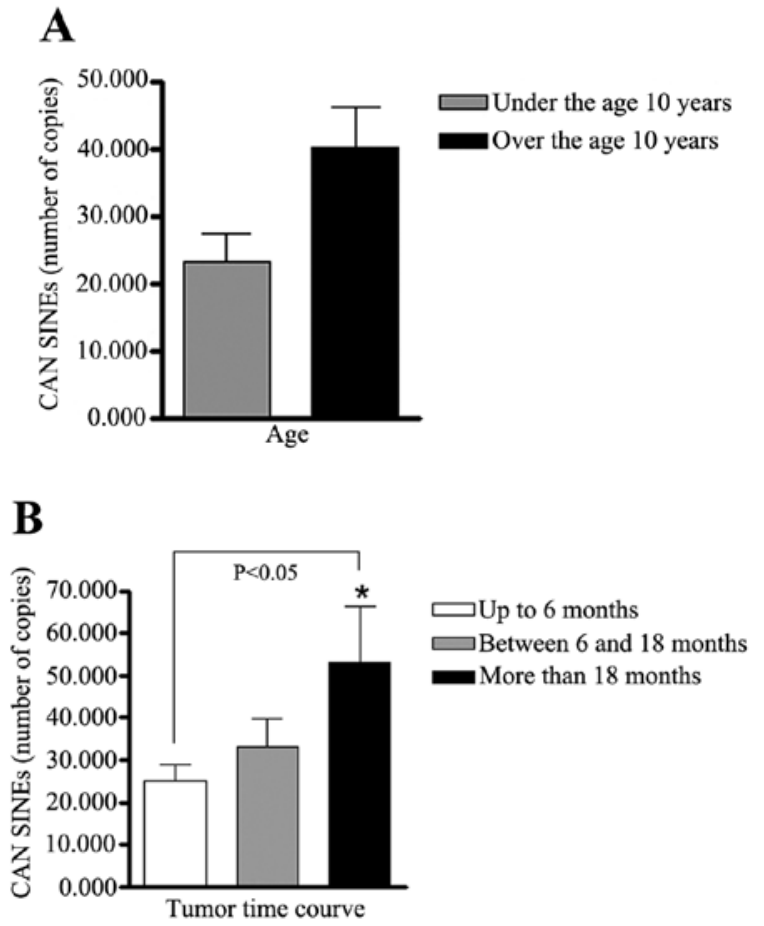

Figure 1. Representation of CAN SINE copies in female dogs with mammary tumor - Correlation between (A) age $(\mathrm{p}=0.02)$ and $(B)$ tumor time course $(\mathrm{p}<0.05)^{*} \mathrm{p}=$ significant difference after the Student's t-test or ANOVA.

separated in groups and compared by the Student's t-test or ANOVA, followed by the Bonferroni test. The association between the characteristics and quantifications with animal death was evaluated by Fisher's exact test. All values were expressed as the mean \pm standard deviation (SD).

The survival curve was constructed following the Kaplan-Meier method. The cut-off points for the CAN SINE measurements were established by the receiver operating characteristic (ROC) curve. Survival curves were plotted using the Kaplan-Meier method and the differences between the curves were evaluated by a log-rank test and hazard function. A multivariate logistic regression analysis was employed to evaluate the simultaneous influence of the prognostic factors on animal death. A p $<0.05$ value was considered statistically significant. All the analyses were done using the GraphPad Prism4 and Stats Direct software.

\section{Results}

The estimated value of CAN SINE sequences in the serum was $1.89 \times 10^{13}$ on $100 \mathrm{ng} / \mu 1$ plasmid. The estimated mean number of CAN SINE copies was 3,197,000 number/ $\mu$ l serum of female dogs with mammary tumors and 3,379,300 number $/ \mu 1$ serum in the control samples with no statistically significant difference $(p=0.7)$ and the mean estimate of the number of copies of female dogs with mammary tumors immediately after surgery and at intervals of one, six and 12 months did not show any statistically significant difference ( $\mathrm{p}>0.05$ ) (Table I). The univariate analysis showed an increase in the number of copies in female dogs with mammary tumor over the age of 10 years $(p=0.02)$ and tumor time of $>18$ months $(p<0.05)$ (Table I) (Fig. 1). 
Table I. Relationship between CAN SINEs copies of dogs with mammary cancer and the clinicopathological parameters.

\begin{tabular}{|c|c|c|}
\hline $\begin{array}{l}\text { Clinicopathological } \\
\text { parameters }\end{array}$ & No. of dogs & CAN SINEs \\
\hline \multicolumn{3}{|l|}{ Clinical feature ${ }^{a}$} \\
\hline Control & 50 & $3,197,000 \pm 4.089$ \\
\hline Samples & 28 & $3,379,300 \pm 3.423$ \\
\hline p-value & & 0.7 \\
\hline \multicolumn{3}{|l|}{$\operatorname{Age}^{a}$} \\
\hline$\leq 10$ years & $15(54 \%)$ & $2,326,000 \pm 4.082$ \\
\hline$>10$ years & $13(46 \%)$ & $4,024,000 \pm 6.006$ \\
\hline p-value & & 0.02 \\
\hline \multicolumn{3}{|l|}{ Histological type ${ }^{a}$} \\
\hline Malignant & $25(89 \%)$ & $2,990,000 \pm 4.143$ \\
\hline Benign & $3(11 \%)$ & $4,923,000 \pm 1.494$ \\
\hline p-value & & 0.2 \\
\hline \multicolumn{3}{|l|}{ Tumor nodules location ${ }^{\mathrm{a}}$} \\
\hline Multiple & $11(39 \%)$ & $3,698,000 \pm 7.007$ \\
\hline Single & $17(61 \%)$ & $2,821,000 \pm 4.845$ \\
\hline p-value & & 0.2 \\
\hline \multicolumn{3}{|l|}{ Tumor size ${ }^{\mathrm{a}}$} \\
\hline $\mathrm{T} 1 / \mathrm{T} 2$ & $14(50 \%)$ & $3,061,000 \pm 5.610$ \\
\hline $\mathrm{T} 3 / \mathrm{T} 4$ & $14(50 \%)$ & $3,333,000 \pm 6.140$ \\
\hline p-value & & 0.7 \\
\hline \multicolumn{3}{|l|}{ Lymph node involvement ${ }^{\mathrm{a}}$} \\
\hline No & $16(57 \%)$ & $2,826,000 \pm 4.877$ \\
\hline $\mathrm{N} 1 / \mathrm{N} 2$ & $12(43 \%)$ & $3,529,000 \pm 5.991$ \\
\hline p-value & & 0.3 \\
\hline \multicolumn{3}{|l|}{ Metastasis $^{\mathrm{a}}$} \\
\hline MO & $23(82 \%)$ & $3,099,000 \pm 4.488$ \\
\hline M1 & $5(18 \%)$ & $4,136,000 \pm 1.055$ \\
\hline p-value & & 0.3 \\
\hline \multicolumn{3}{|l|}{ Time course ${ }^{b}$} \\
\hline Up to 6 months & $13(46 \%)$ & $2,506,000 \pm 3.711^{*}$ \\
\hline Between 6 and 18 months & $10(36 \%)$ & $3,302,000 \pm 6.913$ \\
\hline More than 18 months & $5(18 \%)$ & $5,312,000 \pm 1.330^{*}$ \\
\hline p-value & & $<0.05$ \\
\hline \multicolumn{3}{|l|}{ Tumor recurrence ${ }^{a}$} \\
\hline Yes & $8(28 \%)$ & $2,438,000 \pm 3.715$ \\
\hline No & $20(72 \%)$ & $3,501,000 \pm 5.435$ \\
\hline p-value & & 0.2 \\
\hline \multicolumn{3}{|l|}{ Ulceration $^{\mathrm{a}}$} \\
\hline Yes & $10(36 \%)$ & $2,140,000 \pm 3.004$ \\
\hline No & $18(64 \%)$ & $3,784,000 \pm 5.737$ \\
\hline $\mathrm{p}$-value & & 0.05 \\
\hline \multicolumn{3}{|l|}{ Vascularization $^{\mathrm{a}}$} \\
\hline Abundant & $15(53 \%)$ & $2,978,000 \pm 4.773$ \\
\hline Moderate & $13(47 \%)$ & $3,629,000 \pm 6.951$ \\
\hline p-value & & 0.4 \\
\hline \multicolumn{3}{|l|}{ Clinical staging ${ }^{\mathrm{a}}$} \\
\hline $\mathrm{I} / \mathrm{II}$ & $13(46 \%)$ & $3,049,000 \pm 6.058$ \\
\hline III/IV & $15(54 \%)$ & $3,516,000 \pm 5.788$ \\
\hline p-value & & 0.5 \\
\hline \multicolumn{3}{|l|}{ Censorship $^{a}$} \\
\hline Death & $9(32 \%)$ & $3,250,000 \pm 6.747$ \\
\hline Alive & $19(68 \%)$ & $3,172,000 \pm 5.232$ \\
\hline $\mathrm{p}$-value & & 0.9 \\
\hline
\end{tabular}

Different symbols indicate different statistical analysis. ${ }^{\text {SStudent's }}$ t-test, ${ }^{b}$ ANOVA. * For statistical significant $(\mathrm{p}<0.05)$.

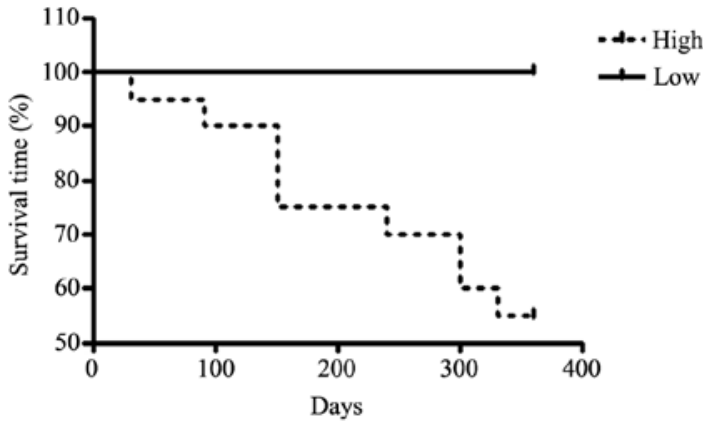

Figure 2. Global survival of female dogs with high and low CAN SINE copies (cut-off value: 19132.00 copies) (OR, 0.1; 95\% CI=0.468104-0.876925; $\mathrm{p}=0.03)$.

Table II. Fisher's exact test in female dogs with mammary tumor and clinicopathological characteristics and CAN SINE copies.

\begin{tabular}{lccc}
\hline Variables & OR & CI 95\% & p-value \\
\hline Tumor recurrence & 18 & $1.79159-231.114723$ & 0.004 \\
Metastasis & Infinity & 2.799376 to infinity & 0.001 \\
Ulceration & 7.5 & $0.966769-64.221665$ & 0.03 \\
CAN SINEs & 0 & $0-0.989268$ & 0.03
\end{tabular}

OR, odds ratio; $\mathrm{CI}$, confidence interval.

Table III. Multivariate logistic regression analysis in female dogs with mammary tumor and clinicopathological parameters.

\begin{tabular}{lrcc}
\hline Variables & OR & CI 95\% & p-value \\
\hline Tumor recurrence & 13.6 & $1.580583-116.364655$ & 0.01 \\
Ulceration & 8.5 & $1.211601-59.656459$ & 0.03 \\
\hline
\end{tabular}

OR, odds ratio; CI, confidence interval.

The female dogs were followed for 30-360 days for the survival curve. They were divided according to the last sample measured before death and, using the ROC curve, the best cut-off point of CAN SINEs to discriminate the high risk of death was $1,913,200$ number $/ \mu 1$ serum [sensitivity $(95 \%$ CI $)=100 \%$, specificity $(95 \% \mathrm{CI})=42 \%$ ]. The KaplanMeier test demonstrated a negative correlation between an increased number of copies and survival time (OR, 0.1; 95\% $\mathrm{CI}=0.468104-0.876925 ; \mathrm{p}=0.03$ ) (Fig. 2 ) where all female dogs with increased number of CAN SINE copies died.

When each clinical pathological characteristic of the test group was associated with higher risk of death, tumor recurrence $(\mathrm{OR}, 18 ; \mathrm{p}=0.004)$, metastasis $(\mathrm{OR}$, infinity; $\mathrm{p}=0.001)$, ulceration $(\mathrm{OR}, 7.5 ; \mathrm{p}=0.03)$ and a higher number of CAN SINE copies $(\mathrm{OR}, 0 ; \mathrm{p}=0.03)$ were statistically significant (Table II). Moreover, the simultaneous influence of prognostic factors and the number of copies on risk of death in female dogs with mammary tumors was correlated with 
tumor recurrence $(\mathrm{OR}, 13.6 ; \mathrm{p}=0.01)$ and ulceration $(\mathrm{OR}, 8.5$; $\mathrm{p}=0.03)$ (Table III).

\section{Discussion}

Technical progress in the detection and the quantification of specific RNAs or DNAs has made disease diagnosis and follow-up possible. Specifically, ctDNA was found to carry tumor-associated genetic alterations and, thus, for more than a decade, it has been considered as a potential biomarker for cancer diagnostics and non-invasive testing $(26,38,39)$, a predictor of the existence, progression and prognosis of breast cancer (40) proportional to the tumoral mass (41) as well as a way to monitor the effect of cancer therapy (30).

Only a few studies have been published on the analysis of the sequences that make up total circulating DNA and the estimation of CAN SINE sequences in dogs does not exist in the literature. PCR and real-time PCR revealed the presence of a number of genes such as p53, the Ras family, Ig Heavy chain, TP53, SRY and DYS1 (for fetal DNA), lamin B2, leptin, $\beta$-Globin, $\beta$-actin and Alu repeats, and a number of other polymorphic markers were used to detect alterations that are similar in tumor and plasma DNA (42). The composition of circulating DNA with regard to the sequence content and the variation in the amount of all or only specific sequences in malignant and other diseases compared to controls is largely unknown.

Elucidating the sequence contents of total circulating DNA may contribute to determining the source and function of circulating DNA (42). Continuing expansion of retrotransposons in humans and its consequences are responsible for several different human genetic disorders. Since the mobility of SINEs in the dogs is even higher than in humans, they may also be the cause of many genetic disorders in dogs. Retrotransposons can disrupt ORFs, alter splicing, or modulate gene expression and may also create genomic deletions upon insertion into host genomes and have a postinsertional impact through unequal homologous recombination (43). Results of Clark et al (44) further suggest that SINE insertions, present in the canine $\mathrm{D} 2$ dopamine receptor gene, the dystrophin gene and the PTPLA gene, implicated in centronuclear myopathy, may also play a significant role in the phenotypic diversity of dog breeds.

Through absolute quantification by qPCR it was possible to estimate, in arbitrary units, the number of copies of CAN SINE sequences in free circulating DNA from cells of mammary tumors of female dogs and it is possible to correlate this data with the clinical and pathological features and survival. In addition, non-invasive monitoring of animals at different sampling times during the onset of the disease is able to help predict and describe accounts of death and/or tumor recurrence and, thus, can be used in establishing the prognosis in breast cancer. Besides that, according to Schwarzenbach et al (29), minimally invasive blood analyses of cell-free nucleic acid allow repetitive real-time monitoring of these events and treatment effectiveness.

No difference was found between the release of CAN SINE copies in DNA in the cancer and the control group, despite the exclusion criteria of the control group being strictly followed. A likely explanation for this is the different categories of
ctDNA: tumor ctDNA from microenvironmental, neoplastic cells and ctDNA from normal extra tumoral cells which arise from several cell types from apoptosis, such as morphogenesis, the immune system, intestinal, mammary differentiation and dedifferentiation, or from necrosis induced by infection, infarction, injury, inflammation or poison, as pointed out by Mouliere et al (26). However, through the univariate and multivariate analysis it was possible to associate the predictive factors of tumor development and poor prognosis with the increased release of CAN SINE copies in free circulating DNA, characterizing it as a potential prognostic marker in breast cancer.

The genetic and epigenetic alterations in plasma DNA have been associated with worse prognosis in several tumor types $(45,46)$. The presence of circulating free DNA in the blood is considered to be a derivative of increased and abnormal apoptotic pathways in the cancerous lesions (27). The abnormal DNA degradation or secretion leads to increased DNA levels and differing DNA fragmentation, readily identifiable with standardized and affordable molecular biology techniques. Necrosis is associated with tumor development, while apoptosis and phagocytosis are associated with defense mechanisms and both lead to the destruction of tumor cells and also the adjacent non-tumor tissues and to DNA fragmentation (24). A study of Schaefer et al (47) found that dogs with lymphoid neoplasia have increased plasma DNA, characterizing it as an indicator of poor prognosis.

The increased amount of copies of the CAN SINEs observed in female dogs with longer tumor times is in agreement with Thierry et al (31) indicating that increased amount of plasma ctDNA is observed as the tumor progresses and high ctDNA levels are found in patients with advanced disease, metastasis and this correlates with shorter survival. The integrity of circulating DNA could have a significant prognostic utility in the detection of breast cancer progression and axillary lymph node metastasis. It is assumed that the DNA released from malignant tumors into the bloodstream is enhanced by lymphovascular invasion and, as a result, circulating DNA may be directly related to tumor progression and rate of tumor cell turnover, representing biologic tumor aggressiveness (37). Furthermore, many benign tumors and preneoplastic regions, a higher rate of cell proliferation is accompanied by a commensurate increase in apoptotic cell death (48). Genetic changes due to apoptosis regulation are usually a fairly late event in tumor development and are involved in tumor progression rather than the start of the process. Mostly, tumor volume is small in the early stages of development but the rate of apoptotic cell death is relatively high. During later stages of tumor development, even if the rate of apoptosis decreases, the total number of apoptotic cells is still high due to the large size of the tumor. Two additional factors, which can affect the level of nucleic acids in circulation, are the degree of tissue vascularization and the clearance of circulating nucleic acids into urine and other compartments (48).

Through the survival curve, it was observed that all the female dogs that died showed an increase in the number of copies of the CAN SINE element, allowing us to propose the hypothesis that the increased release of free circulating DNA is associated with malignant cellular changes that occur during 
the neoplasia process. Moreover, this estimate was considered an independent prognostic marker for survival and can be used to control the staging of breast cancer.

The finding that nuclear DNA of patients with cancer can release the nucleic acids for circulating tumor cells is of crucial importance in the diagnosis of these patients (49). Moreover, the absence of studies focused on markers that define the prognosis for the routine clinical practice for dogs with mammary cancer make this study of fundamental importance (50) especially when the targets are DNA fragments never previously studied in this species.

The wide circulation of CAN SINE copies observed in canine mammary cancer and its relationship to factors of tumor progression and increased risk of death makes it possible to characterize the free circulating DNA, derived from non-LTR retrotransposon, as a potential prognostic marker.

\section{Acknowledgements}

This study was funded by the FAPESP-Fundacao de Amparo a Pesquisa do Estado de Sao Paulo. We would also like to thank Dr Giovanni Cassali for his contribution in the histopathological diagnosis of samples.

\section{References}

1. Schneider R: Comparison of age, sex and incidence rates in human and canine breast cancer. Cancer 26: 419-426, 1970.

2. Mottollese M, Morelli L, Agrimi U, Benevolo M, Sciarretta F, Antonucci G and Natali PG: Spontaneous canine mammary tumors. A model for monoclonal antibody diagnosis and treatment of human breast cancer. Lab Invest 71: 182-187, 1994.

3. MacEwen EG: Spontaneous tumors in dogs and cats: models for the study of cancer biology and treatment. Cancer Metastases Res 9: 125-136, 1990.

4. Peleteiro MC: Tumores mamários na cadela e na gata. Revista Portuguesa de Ciências Veterinárias (in Portuguese) 89: 10-29, 1994.

5. Pinho SS, Carvalho S, Cabral J, Reis CA and Gartner F: Canine tumors: a spontaneous animal model of human carcinogenesis. Transl Res 159: 165-172, 2012.

6. Bentolila S, Bach J, Kessler J, Bordelais I, Cruaud C, Weissenbach J and Panthier J: Analysis of major repetitive DNA sequences in the dog (Canis familiaris) genome. Mamm Genome 10: 699-705, 1999.

7. Stone DM, Jacky PB and Prieur D: The Giemsa banding pattern of canine chromosomes, using a cell synchronization technique. Genome 34: 407-412, 1991.

8. Langford CF, Fischer PE, Binns MM, Holmes NG and Carter NP: Chromosome-specific paints from a high-resolution flow karyotype of the dog. Chromosome Res 3: 1-11, 1995.

9. Fischer PE, Holmes NG, Dickens HF, Thomas R, Binns MM and Nacheva EP: The application of FISH techniques for physical mapping in the dog (Canis familiaris). Mamm Genome 7: 37-41, 1996.

10. Guevara-Fujita ML, Loechel R, Venta PJ, Yuzbasiyan-Gurkan V and Brewer GJ: Chromosomal assignment of seven genes on canine chromosomes by fluorescence in situ hybridization. Mamm Genome 7: 268-270, 1996.

11. Langston AA, Mellersh CS, Neal CL, et al: Construction of a panel of canine-rodent hybrid cell lines for use in partitioning of the canine genome. Genomics 46: 317-325, 1997.

12. Francisco LV, Langston AA, Mellersh CS, Neal CL and Ostrander EA: A class of highly polymorphic tetranucleotide repeats forcanine genetic mapping. Mamm Genome 7: 359-362, 1996.

13. Mellersh CS, Langston AA, Acland GM, et al: A linkage map of the canine genome. Genomics 46: 326-336, 1997.

14. Lingaas F, Sorensen A, Juneja RK, et al: Towards construction of a canine linkage map: establishment of 16 linkage groups. Mamm Genome 8: 218-221, 1997.
15. Belgnaoui SM, Gosden RG, Semmes OJ and Haoudi A: Human LINE-1 retrotransposon induces DNA damage and apoptosis in cancer cells. Cancer Cell Int 6: 13, 2006.

16. Tashiro K, Teissier A, Kobayashi N, et al: A mammalian conserved element derived from SINE displays enhancer properties recapitulating Satb2 expression in early-born callosal projection neurons. PLoS One 6: e28497, 2011.

17. Wessler SR: Eukaryotic transposable elements: teaching old genomes new tricks. In: The Implicit Genome. Caporale L (ed). Oxford University Press, Oxford, pp138-165, 2006.

18. Wicker T, Sabot F, Hua-Van A, et al: A unified classification system for eukaryotic transposable elements. Nat Rev Genet 8: 973-982, 2007.

19. Vassetzky NS and Kramerov DA: CAN - a pan-carnivore SINE family. Mamm Genome 13: 50-57, 2002.

20. Deininger PL and Batzer MA: Alu repeats and human disease. Mol Genet Metab 67: 183-193, 1999.

21. Mouliere F, Robert B, Peyrotte E, et al: High fragmentation characterizes tumour-derived circulating DNA. PLoS One 6: e23418, 2011.

22. Rong-Rong J, Wang $\mathrm{H}$, Cui M, et al: A sensitive method to quantify human cell-free circulating DNA in blood: Relevance to myocardial infarction screening. Clin Biochem 44: 1074-1079, 2011.

23. Mandel P and Metais PCR: Seances. Soc Biol Fil 142: 241-243, 1948.

24. Stroun M, Lyautey J, Lederrey C, Olson-Sand A and Anker P: About the possible origin and mechanism of circulating DNA Apoptosis and active DNA release. Clin Chim Acta 313: 139-142, 2001.

25. Wang BG, Huang HY, Chen YC, et al: Increased plasma DNA integrity in cancer patients. Cancer Res 63: 3966-3968, 2003.

26. Mouliere F and Thierry AR: The importance of examining the proportion of circulating DNA originating from tumor, microenvironment and normal cells in colorectal cancer patients. Expert Opin Biol Ther 12 (Suppl 1): 209-215, 2012.

27. Mead R, Duku M, Bhandari P and Cree IA: Circulating tumour markers can define patients with normal colons, benign polyps, and cancers. Br J Cancer 105: 239-245, 2011.

28. Philipp AB, Stieber P, Nagel D, et al: Prognostic role of methylated free circulating DNA in colorectal cancer. Int J Cancer 15: 2308-2319, 2012.

29. Schwarzenbach H, Hoon DS and Pantel K: Cell-free nucleic acids as biomarkers in cancer patients. Nat Rev Cancer 11: 426-437, 2011.

30. Sozzi G, Conte D, Leon ME, et al: Quantification of free circulating DNA as a diagnostic marker in lung cancer. J Clin Oncol 21: 3902-3908, 2003.

31. Thierry AR, Mouliere F, Gongora C, et al: Origin and quantification of circulating DNA in mice with human colorectal cancer xenografts. Nucleic Acids Res 18: 6159-6175, 2010.

32. Beck J, Urnovitz HB, Riggert J, Clerici M and Schutz E: Profile of the circulating DNA in apparently healthy individuals. Clin Chem 55: 730-738, 2009.

33. Misdorp W, Else RW and Hellmen E: Histological classification of mammary tumors of the dog and cat. In: WHO International Classification of Tumors of Domestic Animals. Armed Forces Institute of Pathology, Washington, DC, pp18-27, 1999.

34. Cassali GD, Lavalle GE, De Nardi AB, et al: Perpectives for diagnosis, prognosis and treatment of mammary neoplasms in dogs. Braz J Vet Pathol 4: 153-180, 2011.

35. Zhang T and Fang HH: Applications of real-time polymerase chain reaction for quantification of microorganisms in environmental samples. Appl Microbiol Biotechnol 70: 281-289, 2006.

36. Liang $\mathrm{H}$ and $\mathrm{Wu} \mathrm{H}$ : Parameter estimation for differential equation models using a framework of measurement error in regression models. J Am Stat Assoc 103: 1570-1583, 2008.

37. Umetani N, Giuliano AE, Hiramatsu SH, Amersi F, Nakagawa T, Martino S and Hoon DS: Prediction of breast tumor progression by integrity of free circulating DNA in serum. J Clin Oncol 24: 4270-4276, 2006.

38. Suzuki N,Kamataki A, Yamaki J and Homma Y: Characterization of circulating DNA in healthy human plasma. Clin Chim Acta 387: 55-58, 2008.

39. Umetani N, Kim J, Hiramatsu S, Reber HÁ, Hines OJ, Bilchik AJ and Hoon DS: Increased integrity of free circulating DNA in sera of patients with colorectal or periampullary cancer: direct quantitative PCR for ALU repeats. Clin Chem 52: 1062-1069, 2006.

40. Sunami E, Vu AT, Nguyen SL, Giuliano AE and Hoon DS: Quantification of LINE1 in circulating DNA as a molecular biomarker of breast cancer. Ann NY Acad Sci 1137: 171-174, 2008. 
41. Diehl F, Schmidt K, Choti MA, et al: Circulating mutant DNA to assess tumor dynamics. Nat Med 14: 985-990, 2008.

42. van der Vaart M and Pretorius PJ: A method for characterization of total circulating DNA. Ann NY Acad Sci 1137: 92-97, 2008.

43. Cordaux R and Batzer MA: Teaching an old dog new tricks: SINEs of canine genomic diversity. Proc Natl Acad Sci USA 103 1157-1158, 2006

44. Clark LA, Wahl JM, Rees CA and Murphy KE: Retrotransposon insertion in SILV is responsible for merle patterning of the domestic dog. Proc Natl Acad Sci USA 103: 1376-1381, 2006.

45. Yang Y, Pospisil P, Iyer LK, Adelstein SJ and Kassis AI Integrative genomic data mining for discovery of potential blood-borne biomarkers for early diagnosis of cancer. PLoS One 3: e3661, 2008.

46. Punnose EA, Atwal S, Liu W, et al: Evaluation of circulating tumor cells and circulating tumor DNA in non-small cell lung cancer: association with clinical endpoints in a phase II clinical trial of pertuzumab and erlotinib. Clin Cancer Res 18: 2391-2401, 2012.
47. Schaefer DM, Forman MA, Kisseberth WC, Lehman AM, Kelbick NT, Harper P and Rush LJ: Quantification of plasma DNA as a prognostic indicator in canine lymphoid neoplasia. Vet Comp Oncol 5: 145-155, 2007.

48. Lichtenstein AV, Melkonyan HS, Tomei LD and Umansky SR: Circulating nucleic acids and apoptosis. Ann NY Acad Sci 945 239-249, 2001

49. Synowiec E, Stefanska J, Morawiec Z, Blasiak J and Wozniak K Association between DNA damage, DNA repair genes variability and clinical characteristics in breast cancer patients. Mutat Res 648: 65-72, 2008.

50. Gelaleti GB, Jardim BV, Leonel C, Moschetta MG and Zuccari DA: Interleukin-8 as a prognostic serum marker in canine mammary gland neoplasias. Vet Immunol Immunopathol 146: 106-112, 2012. 